Harding University

Scholar Works at Harding

English Department Faculty Research and

Publications

English

$3-2014$

\title{
D. H. Lawrence's 'Men Must Work and Women as Well' in Aldous Huxley's Brave New World.
}

Nicholas S. Boone

Harding University, nboone@harding.edu

Follow this and additional works at: https://scholarworks.harding.edu/english-facpub

Part of the English Language and Literature Commons

\section{Recommended Citation}

Boone, N. S. (2014). D. H. Lawrence's 'Men Must Work and Women as Well' in Aldous Huxley's Brave New World.. Notes \& Queries, 61 (1), 133-135. http://dx.doi.org/10.1093/notesj/gjt223

This Article is brought to you for free and open access by the English at Scholar Works at Harding. It has been accepted for inclusion in English Department Faculty Research and Publications by an authorized administrator of Scholar Works at Harding. For more information, please contact scholarworks@harding.edu.

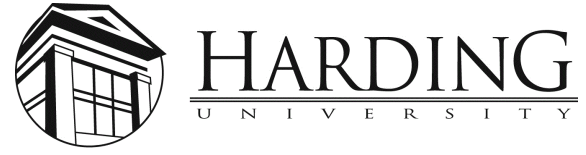




\section{H. Lawrence's 'Men Must Work and Women as Well' in Aldous Huxley's Brave New World}

Aldous Huxley and D. H. Lawrence began developing a close friendship in $1926 .{ }^{1}$ Huxley began writing Brave New World in May of 1931, a little over a year after Lawrence's death in March 1930. While some scholars have pointed to Lawrence's influence on the novel, especially in Huxley's depiction of the New Mexico savage reservation and in his creation of the character of John the savage, ${ }^{2}$ no one has pointed to an essay Lawrence published in November of 1929, a year and a half before the writing of Brave New World, which contains a few of the key themes of Huxley's classic in embryo.

The essay is entitled 'Men Must Work and Women as Well', and it was first published in November 1929 in Star Review. The focus of the essay is the notion that Western civilization has suffered a change in consciousness. It has so long valued the spiritual or ideal that is has finally come to revile anything physical. Lawrence points out two problematic effects of this revulsion. 1) People can no longer abide physical labour-which causes a lot of social problems since physical labour is inescapable, especially amongst the lowest classes. And 2) marriage and family life is threatened since men and women really cannot stand each other physically. They can only exist for one another as purely mental ideals. As Lawrence fleshes out these ideas, at least a few important points of contact between his essay and Brave New World can be seen.

The first point of contact is a similar view of western culture's 'progress' based on its currently accepted values. Lawrence says, 'Everybody hopes it [progress] is flowing towards bigger business and

\footnotetext{
${ }^{1}$ See John Worthen, D. H. Lawrence: The Life of an Outsider, (New York, 2005), 348.

${ }^{2}$ Both Brad Buchanan and Peter Firchow have published essays on Lawrence's influence on Brave New World. Buchanan points out similarities between Lawrence and the character of John the savage, while Firchow sees Huxley using Lawrences social ideas (manifested mostly in the organization of the Savage Reservation) as a counterpoint to the World State. See Brad Buchanan, 'Oedipus in Dystopia: Freud and Lawrence in Aldous Huxley's Brave New World', Journal of Modern Literature, xxv (2002), 75-89, esp. pp. 85-8. Also, see Peter Firchow, 'Wells and Lawrence in Huxley's Brave New World', Journal of Modern Literature v (1976), 260-78, esp. pp. 272-4.
} 
better jobs' which will lead, eventually to 'more money, more congenial labours, and fewer hours' as well as 'freedom from all irksome tasks'. ${ }^{3}$ But all this freedom from labour, Lawrence believes, leads, in the present configuration, only to the greater consumption of meaningless pleasures: 'Men and women shall have nothing to do except enjoy themselves'. . . More films, more motor-cars, more dances, more tennis, and more getting completely away from yourself' (583). This is, of course, a key part of the Brave New World scenario: the World State offers to its citizens easy labor, perfectly fitted to their skill-set (to which they've been conditioned before birth/decanting), and beyond this easy labor, as much 'copulation and the feelies' as they desire. ${ }^{4}$

Another link between Lawrence's essay and Brave New World is Henry Ford. Lawrence points to Ford as the embodiment of the desires of the human heart in the industrial epoch: "Mr. Ford, being in his own way a genius, has realized that what the modern workman wants, just like the modern gentleman, is abstraction. The modern workman doesn't want to be interested in his job. He wants to be as little interested, as nearly perfectly mechanical as possible" (585). Of course, in Brave New World, Ford is the great figure of the World State, the messiah that has brought prosperity and 'freedom' (understood as freedom from toil and freedom to consume entertainment) to the world.

Even though Lawrence sees that 'progress' will lead to less and less, physical contact with the natural world (even suggesting, as does Brave New World, that babies will be 'bred in bottles' - p. 584), ${ }^{5}$ he believes that science is perpetually late in catching up the demands of humanity for abstraction. As he says, 'science still can't wash the dinner-things' yet (584). And, he argues, that as much as Ford has

\footnotetext{
${ }^{3}$ D. H. Lawrence, 'Men Must Work and Women as Well' Phoenix Il: Uncollected Writings, eds. Warren Roberts and Harry T. Moore (New York) 1970, 582-91, cited 582. All further references are cited parenthetically in the text. ${ }^{4}$ Aldous Huxley, Brave New World, (New York, 1932, 1969), cited, p. 230. A broader quotation on the nature of the work required of World State citizens makes the point more clearly: "It's childishly simple. No strain on the mind or the muscles. Seven and a half hours of mild, unexhausting labour, and then the soma ration and games and unrestricted copulation and the feelies. What more could they ask for?" (230). ${ }^{5}$ Lawrence likely gathered the idea of babies being bred in bottles from Huxley, if not in conversation, then in Huxley's previous books, Crome Yellow (1921) and Proper Studies (1927). See Firchow, p. 271.
} 
made his factories all mechanical, abstract, and clean they have to be made out of the rocks and iron of the earth, and these raw materials must be hewn from the earth by direct physical contact. He says, 'Science is supposed to remove these hells [mining pits, etc.] for us. And-it doesn't. Not at all' (587). Thus, even though he predicts greater 'fastidiousness' in regards to cleanliness, ${ }^{6}$ Lawrence believes science can never cure the revulsion from physical contact that ails modern humanity, since a large portion of society must always be fixed into the bottom-tier, laboring classes. He says the only possible cure for the continual lapse of science 'is to make labour as likeable as possible, and try to teach the laboring masses to like it' (587); however, he believes this is unlikely to come to pass. Huxley, in Brave New World, takes this challenge head on. He presents a world in which science has cured what ails humanity-it has made the labouring masses amenable to their condition, through intensive conditioning that begins in-vitro. In Brave New World Huxley directly challenges Lawrence's assumption about science's inability to provide a way out of the problem of labouring people's distaste for their labour.

The primary problem that Lawrence's essay diagnoses in modern culture is the strained relationships between men and women. Men and women are repulsed by physical contact to the extent that close proximity to the body of another person is anathema to many. The loosening up of dress codes and the greater sexual freedom he sees amongst the young is described as 'merely optical' in nature, not truly physical. He says, 'So much nudity, fifty years ago, would have made man and woman quiver through and through. Now, not at all! People flaunt their bodies to show how unphysical they are. The more the girls are not desired, the more they uncover themselves' (589). The lessening of passionate relationships between the sexes is another key link between Lawrence's essay and Brave

\footnotetext{
${ }^{6}$ Lawrence harps on modern 'fastidiousness', as a sign that modern humanity reviles the body and prefers mental abstractions. The work modern people desire is 'almost a pure abstraction, a few switches, and no physical contact, no dirt, which is the inevitable result of physical contact' (585). This coincides with Huxley's emphasis on cleanliness in the World State of Brave New World. A couple of World State maxims are 'cleanliness is next to fordliness', and 'civilization is sterilization' (110).
} 
New World. One thinks of John the Savage's response to Lenina's innocent (from her perspective) come-ons, or his sickness at seeing the close-up kissing and sex of the movie he sees. But even more than the physical features of dress, Huxley may have drawn upon this statement from Lawrence's essay for an outline of the basic arrangements of social interaction between the sexes in his World State: Lawrence writes, 'Young men and women today are together all the time, it will be argued. Yes, but they are together as good sports, good chaps, in strange independence of one another, intimate one moment, strangers the next, hands-off! all the time and as little connected as the bits in a kaleidoscope' (589). Huxley's World State's citizens are all autonomous, living, as they do, in separate apartments. But they spend almost all their time in public, out on dates, playing 'obstacle golf' or going to various amusements, dance halls, etc. They 'copulate' a great deal, but they are encouraged not to see one particular individual too often. It is quite as Lawrence depicts in his essay, 'intimate one moment, strangers the next'.

At the end of his essay, Lawrence suggests that the only way to stop this modern 'progress', born out of hatred of all things physical, is to 'get your bodies back, men and women' (591); and the need to do so is urgent, he says, because disaster looms if humanity continues to exist in this odd state of hating the physical while having to remain physical, doing physical tasks all the time. He points to Soviet Russia as one example of what social chaos can occur if modern anti-physicality continues to progress. Materialism, he says, is 'antiphysical': 'The machine is absolutely material, and absolutely anti-physical-as even our fingers know' (591). Russia's successful revolution against the Tzar's autocracy is not a perfect example of the revolution Huxley imagines in Brave New World that ushers in the World State, but it is, like the Soviet's, a socialistic regime, a big-government nightmare, that is based on materialist principles. At any rate, Lawrence's description of the future he fears if men and women don't get their 'bodies back' is in accord with Huxley's Brave New World scenario: 'all western 
civilization is now mechanized, materialized and ready for an outburst of insanity which shall throw us all into some purely machine-driven unity of lunatics' (591).

Obviously, this short essay by Lawrence doesn't come near to Huxley's book in terms of its explorations of science or ideology that lead up to the installation of the World State. But, in embryonic form, some of the key ideas of Huxley's book can indeed be found in the short essay, 'Men Must Work and Women as Well'. 